GESTÃO

ESTRATÉGICA

EM CIÊNCIA,

TECNOLOGIA E

INOVAC̣ÃO
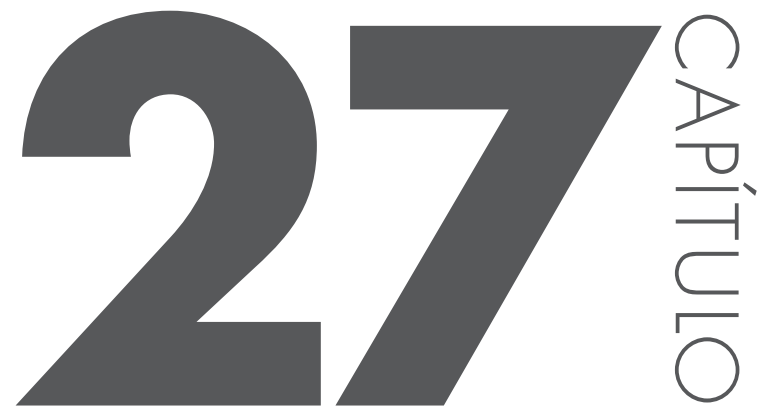

Rodrigo R. Resende

\title{
27.1 INTRODUC̣ÃO
}

Para uma definição mais abrangente sobre "países emergentes”, pode-se dizer que são aqueles países cujas economias partiram de um estágio de estagnação ou subdesenvolvimento e se encontram em pleno desenvolvimento econômico. São também chamados de "países em desenvolvimento". Abaixo apresento as principais características que os países emergentes possuem":

- Padrão de vida de grande parte da população entre os níveis baixo e médio.

- Índice de desenvolvimento humano (IDH) entre os níveis médio e alto.

- Renda per capita (produto interno bruto - PIB - per capita) anual entre 5 e 8 mil dólares.

- Setor industrial em desenvolvimento.

* Vale dizer que um país não precisa apresentar todas as características da lista para ser considerado emergente, mas boa parte delas. 
- Crescimento da infraestrutura (portos, rodovias, aeroportos, ferrovias etc.).

- Atração de capital externo para investimentos nos setor produtivo.

- Aumento da instalação de filiais de grandes empresas multinacionais.

- Crescimento positivo na geração de empregos.

- Taxas elevadas de formação de capital.

- Mudanças significativas e positivas na estrutura social e econômica da população; diminuição da pobreza e aumento da classe média baixa.

- Existência de processo de êxodo rural (migração do campo para os centros urbanos).

As diferenças entre países desenvolvidos e emergentes são inúmeras desde a qualidade e o padrão de hospitais e escolas públicas até a infraestrutura logística dos meios de transporte, passando por diversas outras questões. Obviamente, tanto nos países desenvolvidos quanto naqueles em desenvolvimento há pessoas que desrespeitam leis (se não fosse assim, punições não seriam necessárias) e não têm bom senso suficiente para viver em uma sociedade na qual a cidadania não é colocada em prática e os cidadãos têm poucos direitos de participar da vida política.

Noto, talvez de modo falho, um contraste entre o mundo desenvolvido (cujos cidadãos compartilham do interesse no desenvolvimento enquanto nação) e o mundo em que a cultura do "tirar vantagem" (em serviços públicos e privados, não só nos países em desenvolvimento) é vista como inteligência, "esperteza".

É justamente a diferença entre nação e país que pode transformar uma sociedade marginalizada, e por marginal aqui me refiro àqueles que estão fora do topo da pirâmide da renda per capita, em uma sociedade cuja renda é suficiente para fornecer à população todas as condições necessárias a uma mínima qualidade de vida, desde educação básica até atendimento na primeira hora em um hospital público. Sim, os países em desenvolvimento também têm hospitais e educação de qualidade, mas não vejo a hora de melhorar e chegarmos a sermos um país de primeiro mundo, o que na minha opinião, estamos cada vez mais distantes. Nota-se, entretanto, que a perspectiva de qualidade boa ou ruim é dada com parâmetros pessoais de cada um. Se tivermos a Universidade de Harvard ou o Instituto de Tecnologia de Massachusetts (Massachusetts Institute of Technology, M.I.T.) como parâmetro, veremos que a qualidade dos países subdesenvolvidos arrasta-se aos pés daquelas. Não pelas mentes de nossos cientistas, mas pela falta de infraestrutura e investimentos que veremos a seguir. 
As informações aqui apresentadas constituem uma revisão não muito apurada, justamente para demonstrar que, com pouco esforço e vontade, um Brasil melhor pode ser construído. Cinco pontos foram selecionados para se traçar o caminho para uma nação desenvolvida.

Entre vários estudos avaliados, incluindo aquele do próprio governo (daí não se sabe por que não seguiu suas próprias ideias), todos se destacaram pelo poder comum de síntese ${ }^{1,2,3}$. A maior fonte de crescimento econômico é um nível elevado e sustentado de investimento. No que se refere a "investimento", deve-se levar em conta que este não deve ser considerado no sentido estrito da palavra, mas sim no seu sentido mais amplo, incluindo os recursos humanos (educação de qualidade e aprovada, treinamento e capacitação para a realização de tarefas para as quais há demanda), em inovação tecnológica e organizacional (desde tecnologia de base e avançada até uma estrutura menos burocratizada e mais eficiente), assim como em áreas como as de maquinário e infraestrutura (automatização e transportes mais rápidos e baratos).

Os dados relativos às nações desenvolvidas também sugerem que a abertura comercial e a competição formam o melhor ambiente ao desenvolvimento ${ }^{4}$.

Apresentarei os pontos selecionados, colocando o problema no qual o Brasil se encontra para cada ponto e a solução, tendo como critério os exemplos de nações desenvolvidas e como chegaram até lá.

\subsection{ABERTURA COMERCIAL}

\section{Problema apresentado pelo Brasil}

O potencial de crescimento do Brasil é reduzido pelo fato de ser um dos países mais fechados para o comércio.

\section{Exemplos a serem seguidos}

Tigres Asiáticos, como Taiwan. 


\section{Solução para o desenvolvimento do Brasil}

O processo de globalização, que se intensificou a partir dos anos 1980, beneficiou algumas das principais economias do Sudeste Asiático. Com a redução nas tarifas de importação e o aumento no uso de contêineres, que muito reduziram o custo do transporte marítimo, foi possível às multinacionais distribuir em diferentes regiões do globo o processo de fabricação, usando mão de obra qualificada, mais barata e disponibilidade de recursos naturais disponíveis diretamente no país de fabricação.

A criação de cadeias produtivas globais foi resultado direto dessas mudanças. Atualmente, do total das exportações mundiais, $28 \%$ resultam diretamente de produtos e serviços importados, que, após processamento e incorporação a novas linhas de produção, retornam novamente ao mercado exterior.

Cada cadeia produtiva local especializou-se em nichos específicos de atuação. Taiwan é um exemplo nas áreas de computação e telecomunicações e apresentou um resultado em suas vendas externas que soma em torno de 300 bilhões de dólares, $25 \%$ a mais do que as brasileiras. Seu exemplo mostra que para aumentar as exportações foi preciso elevar as importações.

Tomando as exportações da Coreia do Sul como exemplo, temos a impressionante marca de mais de $60 \%$ ligados a cadeias internacionais, quase o dobro do percentual do Brasil. Nos censos de 2013-2015 do capital estrangeiro, as empresas brasileiras conectadas às cadeias produtivas globais apresentaram resultados de exportação maiores, foram mais produtivas e suas participações no aumento do PIB nacional foram mais proeminentes do que os das demais. De acordo com o estudo Cadeias Globais e Desenvolvimento, publicado pela Conferência das Nações Unidas para o Comércio e Desenvolvimento (United Nations Conference on Trade and Development - UNCTad), existe uma clara correlação entre o crescimento econômico de nações e suas participações nesses sistemas de produção internacionais ${ }^{5}$.

Desde os últimos anos da década de 90 , as nações que integraram cadeias produtivas globais tiveram uma taxa de elevação do PIB per capita cerca de dois pontos percentuais acima da média. O crescimento do PIB de um país emergente tem que, necessariamente, ser muito mais atrativo do que os meros $1 \%$ a $2 \%$ a que atualmente crescemos. As nações mais ricas do mundo, considerando somente as desenvolvidas, têm o crescimento de seu PIB nessa faixa, mas é preciso observar que um país desenvolvido crescer a essas taxas é diferente de um país dito emergente crescer a essas mesmas taxas. Consideremos uma empresa com um faturamento de 100 mil reais 
que passa a faturar 110 mil reais, apresentando uma taxa de crescimento de $10 \%$. Agora imaginemos uma empresa com faturamento anual de 1 milhão de reais e outra com faturamento de 10 milhões de reais. Mesmo com um crescimento percentual menor que $10 \%$, em valores brutos elas crescerão bem mais que os 10 mil reais apresentados pela microempresa. O mesmo vale para a economia do Brasil, que tem um PIB em torno de 1,5-2,0 trilhões de dólares. Um acréscimo de 15-20 bilhões de dólares em sua economia representa um crescimento de apenas 1\%. Comparando com os Estados Unidos, os mesmos $1 \%$ de crescimento representam um acréscimo de cerca de 170 bilhões de dólares. Para sair de um PIB medíocre, é preciso que o Brasil se abra para o comércio ${ }^{6}$.

Além da produção em si, a maneira por meio da qual se dá o processo de produção também é importante. Para comparação, tomemos como exemplo México e Taiwan. Ambos produzem microcomputadores (PCs); porém, os asiáticos fabricam chips e inovam, enquanto o México se restringe à montagem $^{7}$, atuando como mero coadjuvante.

Esse exemplo demonstra claramente que a posição de um país dentro da cadeia produtiva pode colocá-lo em destaque quanto ao seu grau de desenvolvimento. Basta comparar o PIB per capita de ambos os países. O do México é de cerca de 9.700 dólares por habitante, enquanto o de Taiwan é mais que o dobro desse valor".

\subsection{INFRAESTRUTURA TECNOLÓGICA}

\section{Problema apresentado pelo Brasil}

Os serviços de telecomunicações do Brasil são de péssima qualidade e possuem valores abusivos, o que afeta o fluxo de transmissão de dados entre pessoas e empresas.

\section{Exemplo a ser seguido}

Coreia do Sul.

* Pesquisa disponível em: http://pt.knoema.com/atlas/M\%C3\%A9xico/?compareTo=TW. Acesso em: 29 mar. 2016. Dados de 2014. 


\section{Solução para o desenvolvimento do Brasil}

Toda nação que almeja o desenvolvimento tem como base planos de metas a serem atingidos em um determinado prazo. Exceto por aqueles que almejam atingir números negativos, todos os outros traçam planos que possam elevá-los a patamares mais altos do que aquele que ocupavam anteriormente. O governo da Coreia do Sul, no início dos anos 1990, elegeu o setor de tecnologia da informação (TI) como prioridade e definiu a criação de uma rede de banda larga como sua principal meta. Nesse ponto, definir o padrão de qualidade de suas conexões acima do padrão internacional foi crucial para que o país pudesse atingir um patamar superior ao de qualquer outra localidade do planeta. Outra meta traçada pelo governo foi eliminar as barreiras de entrada para novas operadoras de telecomunicação, estimulando a competição por preços mais baixos - a chamada livre concorrência, ponto apresentado anteriormente neste capítulo.

Atualmente, a Coreia do Sul é o país com a maior rede de fibra óptica por habitante. Também é tida como referência nos estudos sobre o impacto da infraestrutura de tecnologia da informação no crescimento econômico, o que pode ser demonstrado pelo seu PIB, cuja expansão de cerca de $20 \%$ nos últimos cinco anos está diretamente relacionada ao avanço do setor de TI.

$\mathrm{O}$ acesso à informação de maneira rápida e confiável permite um aumento de produtividade tanto pessoal quanto empresarial. O fluxo de informações na era da internet é o que conecta agilidade no processamento de informações e produção de conhecimento.

Segundo relatório de 2009 do Banco Mundial, cada aumento de dez pontos percentuais nas conexões de internet banda larga de um país corresponde a um crescimento adicional de 1,3 ponto percentual no PIB.

Hoje, no Brasil, temos mais de 100 milhões de usuários de banda larga, mesmo considerando que as conexões sejam, em geral, de péssima qualidade e com preços exorbitantes. Em estudos recentes de uma empresa americana de internet, a Akamai, e da Agência Nacional de Telecomunicações (ANATEL), sumarizados pela Teleco", a velocidade média da banda larga no Brasil é de 4,1 megabits por segundo (Mbps). Certamente, esse valor aumentou com o passar dos anos; o caso é que aumenta menos que a média dos outros países emergentes ou desenvolvidos. A velocidade de conexão média global aumentou 3,5\% para 5,1 Mbps, no segundo trimestre de 2015. o que nos coloca na $93^{a}$ posição em um ranking de 243 países - abaixo da média

* Ver http://www.teleco.com.br/blarga1.asp. 
mundial, que é de 5,1 Mbps (Tabelas 27.1 a 27.3) ${ }^{8}$. Essa posição vem piorando nos últimos anos (dados até 2016). Em relação aos países da América Latina, de acordo com esse estudo, batizado de State of the Internet, o Brasil é o $8^{\circ}$ país, ficando atrás de Uruguai $(6,7 \mathrm{Mbps})$, Chile (5,7 Mbps), México (4,9 Mbps), Argentina (4,6 Mbps), Colômbia (4,5 Mbps), Peru (4,5 Mbps) e Equador $(4,1 \mathrm{Mbps})^{8}$.

Tabela 27.1 Estatísticas Gerais da População e Economia Brasileiras como Valores Referenciais

\begin{tabular}{cccccccc}
\hline BRASIL & 2009 & 2010 & 2011 & 2012 & 2013 & 2014 & 2015 \\
\hline Populaçãa* & 194.351 & 196.289 & 198.172 & 200.000 & 201.774 & 203.492 & 205.156 \\
\hline PIB RS BILHÕES & 3.333 & 3.886 & 4.374 & 4.806 & 5.316 & 5.687 & 5.904 \\
\hline Cresc. Anual & $(0,1 \%)$ & $7,5 \%$ & $3,9 \%$ & $1,9 \%$ & $3,0 \%$ & $0,1 \%$ & $(3,8 \%)$ \\
\hline PIB US\$ Bilhões & 1.673 & 2.210 & 2.613 & 2.459 & 2.461 & 2.416 & 1.769 \\
\hline PIB PER CAPITA RS & 17.221 & 19.877 & 22.157 & 24.121 & 26.446 & 28.048 & 28.876 \\
\hline Cresc. Anual & $(1,2 \%)$ & $6,5 \%$ & $2,9 \%$ & $1,0 \%$ & $2,1 \%$ & $(0,8 \%)$ & $(4,6 \%)$ \\
\hline PIB per capita US\$ & 8.642 & 11.303 & 13.237 & 12.342 & 12.244 & 11.914 & 8.651 \\
\hline Inflação - IGPM (\%) & $-1,72$ & 11,32 & 5,10 & 7,81 & 5,53 & 2,66 & 10,54 \\
\hline Inflação IPCA (\%) & 4,31 & 5,92 & 6,50 & 5,84 & 5,91 & 6,40 & 10,67 \\
\hline Câmbio fechamento (R\$ por US\$) & 1,74 & 1,67 & 1,88 & 2,04 & 2,34 & 2,66 & 3,90 \\
\hline
\end{tabular}

* Alteração de acordo com revisão 2013 da população feita pelo IBGE. Valores entre parênteses correspondem a negativos.

Tabela 27.2 Velocidade Média da Banda Larga no Brasil

\begin{tabular}{cccccccccc} 
KBPS & 2007 & 2008 & 2009 & 2010 & 2011 & 2012 & 2013 & 2014 & 2015 \\
\hline Velocidade Média & 863 & 1.025 & 1.388 & 1.704 & 1.803 & 2.331 & 2.700 & 3.000 & 4.100 \\
\hline
\end{tabular}

Fonte: Akamai Technologies, $\ln c^{8}$ 
Tabela 27.3 Posição do Brasil em Rankings Mundiais de Tecnologia de Informação e Comunicação

\begin{tabular}{cccccccccc}
\hline & 2007 & 2008 & 2009 & 2010 & 2011 & 2012 & 2013 & 2014 & 2015 \\
\hline GCI - WEF & 72 & 64 & 56 & 58 & 53 & 48 & 56 & 57 & 75 \\
\hline NRI & 53 & 59 & 59 & 61 & 56 & 65 & 60 & 69 & 84 \\
\hline IDI UIT & 61 & 64 & 0 & 67 & 62 & 62 & 65 & 61 & 61 \\
\hline $\begin{array}{c}\text { GLOBAL INNOVATION } \\
\text { INDEX (GII) }\end{array}$ & 40 & 0 & 50 & 68 & 47 & 58 & 64 & 61 & 70 \\
\hline
\end{tabular}

Fonte: World Economic Forum e UIT ${ }^{9}$

Legenda: $\mathrm{GCI}-$ WEF = Global Competitiveness Index - World Economic Forum; NRI = Networked Readiness Index; IDI UIT = ICT (Information and communication technologies) Development Index (IDI). Estes são índices internacionais baseados em acordos multilaterais de tecnologias de informação e comunicação. 0 Global Innovation Index (GII) tem como objetivo capturar as múltiplas facetas da inovaç̦ão e fornecer as ferramentas que possam ajudar na adaptação das políticas para promover o crescimento de longo prazo, a melhoria da produtividade e o crescimento do emprego. 0 Gll ajuda a criar um ambiente no qual os fatores de inovação são continuamente avaliados. Ele fornece uma ferramenta-chave e um rico banco de dados de métricas detalhadas para 141 economias no ano 2015, que representam $95,1 \%$ da populaç̃̃o mundial e $98,6 \%$ do PIB global.

Em relação ao custo da internet, o Brasil possui a segunda internet mais cara do mundo, de acordo com uma pesquisa realizada pela Fundação Getulio Vargas (FGV). O cálculo, que relaciona o preço médio da banda larga à renda per capita da população em 15 países, constatou que o brasileiro precisa trabalhar 5,01 horas por mês para pagar por uma conexão à rede de 1 Mbps. A Argentina está em primeiro lugar no ranking: lá esse número é de 5,15 horas mensais.

Segundo a FGV, o preço médio da conexão de $1 \mathrm{Mbps}$ em terras brasileiras é de 25,06 dólares (em março de 2016, aproximadamente 90 reais), e mais de $40 \%$ desse valor corresponde a impostos cobrados pelo serviço, enquanto o Japão, que exige apenas 0,015 hora de trabalho por mês, cobra somente $5 \%{ }^{10}$. Outros países considerados no mesmo patamar que o Brasil, como Chile e Portugal, têm o serviço pago com 2,50 horas e 1 hora, respectivamente, de trabalho"10. Essas horas de trabalho são relacionadas ao dólar; então, se a moeda local se desvaloriza, pior será a colocação do país em análise. Se considerarmos o ano de 2013 no Brasil, em que a média da cotação do dólar eram $\mathrm{R} \$ 2,15$, a situação piorou quando consideramos que esse valor aumenta ainda mais.

* Maiores detalhes podem ser obtidos no site http://www.cps.fgv.br/cps/telefonica/. 
Além de ter uma das cargas tributárias mais altas do mundo, beirando os $36 \%$, o número de operadoras de internet em funcionamento em um país com dimensões continentais como o Brasil é mínimo, o que diminui a concorrência e permite a cobrança de preços abusivos. Só para termos uma noção da carga tributária mencionada acima, listo alguns exemplos. Em dez estados e no Distrito Federal, apenas o ICMS é de $25 \%$, enquanto em outros chega a 35\%, como em Rondônia. A maioria dos impostos é calculada sobre a receita bruta; a conta telefônica, por exemplo, inclui todos os impostos. Para os estados com ICMS de $25 \%$, os principais impostos e taxas (Cofins, PIS/Pasep, ICMS, Fust e Funtel) equivalem a 30\% do valor da conta, mas se calculados sobre o valor líquido chegam a $43 \%$. Nos estados com ICMS mais alto, a carga tributária total é mais elevada, chegando a 49\% em Rondônia.

É a lei da oferta e procura. Se tivermos um setor com pouca competição e cuja regulação seja ineficiente, isso tornará o consumidor refém dos preços cobrados, o que prejudica e bloqueia o desenvolvimento do país.

Em maio de 2010, foi lançado pelo Ministério das Comunicações um Plano Nacional de Banda Larga (PNBL), por meio do Decreto $\mathrm{n}^{\circ}$ 7.175, porém, seus resultados ainda são incipientes. O objetivo do PNBL é acelerar o acesso da população à sociedade da informação, e um dos principais instrumentos para sua execução é a Telebras, a companhia federal de telecomunicações inativa desde a privatização das telefônicas estaduais em 1998 e que, sob a supervisão do Ministério das Telecomunicações, foi ressuscitada com esse propósito. Outro problema de fácil identificação é que a Lei Geral das Telecomunicações mantém o anacronismo de priorizar a telefonia fixa ${ }^{11}$. Um dos problemas que o Brasil encontra na ineficiência da banda larga é a questão da qualidade. Como sucessivos governos passam a ideia de que universalização do acesso é mais importante do que qualidade, o plano mencionado acima exigia que as operadoras oferecessem seus serviços com preços baixos, porém sem considerar a qualidade como um fator primordial. Em 2013, o governo anunciou que investiria pesadamente em infraestrutura, levando fibra óptica para as 5.570 cidades do Brasil - atualmente, em torno de 3.643 cidades são conectadas por essa tecnologia, ainda que a qualidade deixe a desejar, e as redes são administradas pelas quatro maiores companhias do setor (Vivo, Claro, TIM e Oi) ${ }^{11}$.

Em 2012, as vendas do setor de tecnologia da informação corresponderam a $5,2 \%$ do PIB brasileiro. Nas nações ricas, esse percentual fica entre $7 \%$ e $8 \%$. Valores esses que, temos de considerar, sofrem aumentos ano após ano. De acordo com o $15^{\circ}$ Relatório Global de Tecnologia da Informação, 
divulgado pelo Fórum Econômico Mundial ${ }^{9}$, o Brasil está em $84^{\circ}$ lugar no ranking de competitividade no setor de Tecnologia da Informação (TI), que avalia a influência e impactos da Tecnologia da Informação e Comunicação (TIC) para o desenvolvimento de 144 países ${ }^{9}$. Uma queda de 15 posições desde o ano passado e de 19 posições desde 2012. O país ficou atrás até de populações economicamente menos desenvolvidas como El Salvador ou Ruanda9.

A edição de 2015 do Relatório Global de Tecnologia de Informação apontou para o crescente abismo digital existente entre países, sendo que apenas uma menor parte da população do mundo é beneficiada economicamente e socialmente pelo uso das tecnologias. O estudo indicou como as economias emergentes não exploram o potencial das tecnologias de informação e comunicações para conduzir a transformação social e econômica necessária para que possam atingir o nível das economias mais avançadas.

De acordo com o estudo, apenas $39 \%$ da população mundial tem acesso à internet, apesar de mais de metade possuir um telefone celular ${ }^{9}$. Como era de se esperar, a edição 2015 do Relatório indicou que as economias de alta renda ocupam os 30 primeiros lugares. Singapura é o país que melhor aproveita as TICs para o impacto social e econômico, seguido da Finlândia e da Suécia. São 7 países europeus, 2 asiáticos e apenas um americano entre os 10 melhores colocados.

Com base em dados de 2012, ele sugere que o país trabalhe com a meta de quase dobrar o mercado local de TI até 2022, saindo do faturamento atual, que equivale a 123 bilhões de dólares, e chegando a 230 bilhões de dólares ${ }^{12}$. Entretanto, nos anos de 2012-2016 o Brasil desabou em investimentos.

O desempenho do Brasil é particularmente sombrio no ambiente político e regulatório e nos pilares dos ambientes de negócios de inovação, onde ocupa a $95^{\mathrm{a}}$ e $121^{\mathrm{a}}$ posições, respectivamente (embora tenha melhorado com 14 lugares na última categoria). O nível de tributação do país ( $137^{\mathrm{a}}$ posição), e a medida do seu tapete vermelho - o Brasil classifica-se notadamente em $137^{a}$ posição para o tempo necessário para se iniciar um negócio - e atrasos de seu sistema judiciário estão entre as muitas fraquezas institucionais que explicam esta situação. A falta de preparação da população $\left(108^{a}\right)$, medida pelo nível geral de educação, atua como outro empecilho para a capacidade do país em aproveitar as Tecnologias de Informação e Comunicação (TIC) mais plenamente. Vai ver que é por isso que o tempo do brasileiro em uso da internet é desperdiçado em redes sociais, ao invés de se enriquecer em conhecimentos. A utilização das TIC entre a população tem vindo a melhorar, mas não tão rapidamente como em outros países, fazendo com que o Brasil 
escorregue para baixo do ranking para $62^{a}$ nesta dimensão. Além disso, o governo não conseguiu fazer a TIC um controlador central de sua estratégia de desenvolvimento $\left(106^{\mathrm{a}}\right)$, previsto em 2012, sugerindo que não cumpre com o que se planeja, ou não tem competência para tal. Por conseguinte, os benefícios econômicos e sociais da TIC permanecem muito limitados $\left(76^{\mathrm{a}} \mathrm{e}\right.$ $73^{a}$ posições, respectivamente $)^{9}$.

Um dos requisitos básicos para qualquer nação que queira crescer e que possa fornecer melhor qualidade de vida para sua população, à semelhança de qualquer pessoa que queira crescer em uma empresa e, assim, oferecer maior conforto para sua família, é tornar-se competitivo internacionalmente, por isso, o estudo da McKinsey \& Company apresenta a relevância de se aumentar as exportações de $2 \%$ das receitas do setor de tecnologia da informação para $8 \%$. Atingindo esses objetivos, 1,5 milhão de empregos diretos poderão ser criados, além de se disseminar o uso da TI e da internet rápida entre hospitais, escolas, órgãos públicos e pequenas e médias empresas de todo o país.

Para se alcançar esses objetivos, um obstáculo precisa ser superado: exatamente o da melhora na qualidade da rede de banda larga do país, finaliza o estudo da McKinsey ${ }^{12}$. Notadamente, são ações sugeridas em 2012, porém até então as medidas para estas ações não foram efetivadas imediatamente - algo que os coreanos já fazem desde os anos 90.

\subsection{INOVAC̣ÃO E EMPREENDEDORISMO}

\section{Problema apresentado pelo Brasil}

O país ocupava o $64^{\circ}$ lugar no índice global de inovação, em uma lista com 142 países, segundo estudo da Organização Mundial de Propriedade Intelectual (OMPI) com a Universidade de Cornell (EUA) e a escola de administração francesa Insead, de 2013. Em 2015, passou a ocupar o $70^{\text {a }}$ lugar ${ }^{9}$.

\section{Exemplo a ser seguido}

Israel. 


\section{Solução para o desenvolvimento do Brasil}

Segundo relatório produzido pela Thomson Reuters, o Brasil ocupa o $14^{\circ}$ lugar como produtor mundial de pesquisas - um salto de três posições desde 2001 -, mas a burocracia e a falta de investimento ainda emperram o processo de desenvolvimento do setor. Sem inovação, não conseguiremos ter produtos atrativos que gerem interesse no mercado internacional, e nesse quesito o Brasil também não tem sido eficiente. Em 2013, o país ocupava o $64^{\circ}$ lugar no índice global de inovação, numa lista com 142 países, segundo estudo da Organização Mundial de Propriedade Intelectual (OMPI) com a Universidade de Cornell (EUA) e a escola de administração francesa Insead, seis posições a menos que em 2012 ! Em 2015, o país caiu para $70^{a}$ posição .

Israel foi fundado em 1948, com uma geografia que consiste em um deserto ao sul (o deserto de Negev, que corresponde a $16 \mathrm{mil} \mathrm{Km}^{2}$ dos seus 27 mil Km² de território) e montanhas cobertas por neve ao norte. Um território com bens naturais muito escassos, bem ao contrário do Brasil, cujo território de $8.515 .767 \mathrm{Km}^{2}$ inclui $8.460 .415 \mathrm{Km}^{2}$ de terra e $55.352 \mathrm{Km}^{2}$ de água. A nação israelense - já que seu povo, apesar de distribuído em diferentes continentes, levanta-se para apoiar esse ínfimo pedaço de terra -, passou as últimas décadas investindo em tecnologia para compensar seus escassos recursos naturais. Hoje, Israel é um dos cinco maiores produtores de patentes por habitante do mundo, ficando atrás somente de Estados Unidos, Japão, Suíça e Finlândia.

Em 2012, obteve o registro de quase 2,5 mil patentes nos Estados Unidos, enquanto o Brasil não chegou a 270. Israel também apresenta a maior densidade de empresas de tecnologia do mundo. São 4,8 mil em uma população de 8 milhões. No Brasil, temos cerca de 10 mil empresas de tecnologia para uma população de pouco mais de 200 milhões de habitantes. E ainda é preciso considerar que muitas dessas empresas existem somente no papel e não desenvolvem e nem produzem nada de novo. Aliás, quando se diz que há uma inovação, são produtos cujas partes são importadas e montadas para revenda. Obviamente existem exceções, mas são a minoria, como será discutido adiante.

Considerando os países membros do BRICS e a Coreia do Sul, para efeito de comparação, o Brasil encontra-se somente na faixa da África do Sul em relação ao número de pedidos e concessões de patentes de invenção nos Estados Unidos, o maior mercado consumidor e produtor (Figura 27.1).

Israel também ocupa o primeiro lugar no ranking que mede o percentual de investimento do PIB em pesquisa em desenvolvimento: 4,5\%. O Brasil 




Figura 27.1 Pedidos e concessões de patentes de invenção junto ao Escritório Americano de Marcas e Patentes (USPTO, na sigla em inglês) de países selecionados, 1999-2014. Países BRICS* e Coreia do Sul.

Fonte(s): Escritório Americano de Marcas e Patentes (USPTO, na sigla em inglês), $2015^{13}$.

investe $1 \%$ (Figuras 27.2 a 27.4 e Tabela 27.4). Como um país do tamanho de Sergipe conseguiu tudo isso?

Tabela 27.4 Brasil: Comparação dos dispêndios em pesquisa e desenvolvimento (P\&D) com o produto interno bruto (PIB) (2000-2013, em milhões de R\$ e valores de 2013)'

\begin{tabular}{|c|c|c|c|c|c|c|c|c|c|c|c|c|c|c|}
\hline & 2000 & 2001 & 2002 & 2003 & 2004 & 2005 & 2006 & 2007 & 2008 & 2009 & 2010 & 2011 & $2012(2)$ & $2013(2)$ \\
\hline \multicolumn{15}{|c|}{ TOTAL } \\
\hline $\begin{array}{l}\text { Dispêndios } \\
\text { em P\&D }\end{array}$ & $34.655,4$ & $35.664,4$ & $34.909,8$ & $34.990,1$ & $35.666,8$ & $38.278,9$ & $39.253,5$ & $45.584,9$ & $49.977,6$ & $49.438,1$ & $55.048,2$ & $56.239,3$ & $57.786,6$ & $63.748,6$ \\
\hline $\begin{array}{c}\text { Índice } \\
(2000=100)\end{array}$ & 100,0 & 102,9 & 100,7 & 101,0 & 102,9 & 110,5 & 113,3 & 131,5 & 144,2 & 142,7 & 158,8 & 162,3 & 166,7 & 184,0 \\
\hline $\begin{array}{c}\text { \% em relação } \\
\text { ao PIB }\end{array}$ & 1,04 & 1,06 & 1,01 & 1,00 & 0,96 & 1,00 & 0,99 & 1,08 & 1,13 & 1,12 & 1,16 & 1,14 & 1,15 & 1,24 \\
\hline
\end{tabular}

* Em economia, BRICS é um acrônimo que se refere aos países membros fundadores (o grupo BRIC: Brasil, Rússia, Índia e China) e à África do Sul, que juntos formam um grupo político de cooperação. Em 14 de abril de 2011, o "S" foi oficialmente adicionado à sigla BRIC para formar o BRICS, após a admissão da África do Sul (em inglês, South Africa) ao grupo. Os membros fundadores e a África do Sul estão todos em um estágio similar de mercado emergente, devido ao seu desenvolvimento econômico. É geralmente traduzido como "os BRICS" ou "países BRICS" ou, alternativamente, como os "Cinco Grandes". 


\begin{tabular}{|c|c|c|c|c|c|c|c|c|c|c|c|c|c|c|}
\hline & 2000 & 2001 & 2002 & 2003 & 2004 & 2005 & 2006 & 2007 & 2008 & 2009 & 2010 & 2011 & $2012(2)$ & $2013(2)$ \\
\hline \multicolumn{15}{|c|}{ DISPÊNDIOS PÚBLICOS } \\
\hline $\begin{array}{c}\text { Dispêndios } \\
\text { em P\&D }\end{array}$ & $17.916,8$ & $19.009,6$ & $18.023,7$ & $17.987,2$ & $17.652,8$ & $18.245,0$ & $19.639,3$ & $23.531,1$ & $25.167,2$ & $25.853,4$ & $28.138,2$ & $29.748,7$ & $31.743,0$ & $36.783,7$ \\
\hline $\begin{array}{c}\text { Índice } \\
(2000=100)\end{array}$ & 100,0 & 106,1 & 100,6 & 100,4 & 98,5 & 101,8 & 109,6 & 131,3 & 140,5 & 144,3 & 157,0 & 166,0 & 177,2 & 205,3 \\
\hline $\begin{array}{l}\text { \% em relacãón } \\
\text { ao PIB }\end{array}$ & 0,54 & 0,57 & 0,52 & 0,51 & 0,48 & 0,48 & 0,49 & 0,56 & 0,57 & 0,59 & 0,59 & 0,60 & 0,63 & 0,71 \\
\hline
\end{tabular}

GOVERNO FEDERAL

\begin{tabular}{cccccccccccccccc}
\hline $\begin{array}{c}\text { Dispêndios } \\
\text { em P\&D }\end{array}$ & $11.057,4$ & $11.647,6$ & $11.213,1$ & $11.825,2$ & $12.136,9$ & $12.464,2$ & $13.987,8$ & $16.185,6$ & $17.179,4$ & $17.849,8$ & $19.589,4$ & $20.053,2$ & $21.324,0$ & $25.802,5$ \\
\hline $\begin{array}{c}\text { Índice } \\
(2000=100)\end{array}$ & 100,0 & 105,3 & 101,4 & 106,9 & 109,8 & 112,7 & 126,5 & 146,4 & 155,4 & 161,4 & 177,2 & 181,4 & 192,8 & 233,4 \\
\hline $\begin{array}{c}\text { \% em relação } \\
\text { ao PIB }\end{array}$ & 0,33 & 0,35 & 0,32 & 0,34 & 0,33 & 0,33 & 0,35 & 0,38 & 0,39 & 0,40 & 0,41 & 0,41 & 0,42 & 0,50
\end{tabular}

\section{GOVERNO ESTADUAL}

\begin{tabular}{ccccccccccccccc}
\hline $\begin{array}{c}\text { Dispêndios } \\
\text { em P\&D }\end{array}$ & $6.859,4$ & $7.362,0$ & $6.810,7$ & $6.161,9$ & $5.515,9$ & $5.780,8$ & $5.651,6$ & $7.345,4$ & $7.987,8$ & $8.003,6$ & $8.548,8$ & $9.695,5$ & $10.419,0$ & $10.981,3$ \\
\hline $\begin{array}{c}\text { Índice } \\
(2000=100)\end{array}$ & 100,0 & 107,3 & 99,3 & 89,8 & 80,4 & 84,3 & 82,4 & 107,1 & 116,4 & 116,7 & 124,6 & 141,3 & 151,9 & 160,1 \\
\hline $\begin{array}{c}\text { \% em relação } \\
\text { a0 PIB }\end{array}$ & 0,21 & 0,22 & 0,20 & 0,18 & 0,15 & 0,15 & 0,14 & 0,17 & 0,18 & 0,18 & 0,18 & 0,20 & 0,21 & 0,21 \\
\hline
\end{tabular}

\section{SETOR EMPRESARIAL}

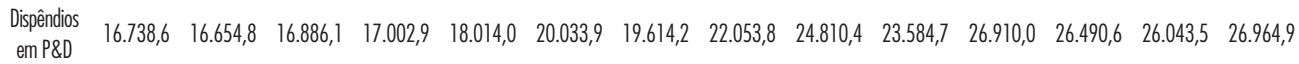

\begin{tabular}{|c|c|c|c|c|c|c|c|c|c|c|c|c|c|c|}
\hline $\begin{array}{c}\text { Índice } \\
(2000=100)\end{array}$ & 100,0 & 99,5 & 100,9 & 101,6 & 107,6 & 119,7 & 117,2 & 131,8 & 148,2 & 140,9 & 160,8 & 158,3 & 155,6 & 161,1 \\
\hline $\begin{array}{c}\text { \% em relacãão } \\
\text { a0 PIB }\end{array}$ & 0,50 & 0,50 & 0,49 & 0,49 & 0,49 & 0,52 & 0,49 & 0,52 & 0,56 & 0,53 & 0,57 & 0,54 & 0,52 & 0,52 \\
\hline
\end{tabular}

Fonte(s): Coordenação-Geral de Indicadores (CGIN) - ASCAV/SEXEC - Ministério da Ciência, Tecnologia e Inovação (MCTI) $)^{14}$.

Nota(s): 1) Valores obtidos através dos multiplicadores utilizados pelo Banco Central para deflacionar o PIB, publicados na tabela "Produto Interno Bruto e taxas médias de crescimento" em http://www.bcb.gov.br/? INDECO. 2) Dados preliminares.

A Tabela 27.4 pode ser melhor visualizada por meio gráficos das Figuras 27.3 e 27.4 , que deixam claro que os investimentos em pesquisa e desenvolvimento (P\&D) dos governos federal e estadual não crescem anualmente, mas sim, em alguns anos, decrescem. Talvez isso ocorra porque o setor público não consegue perceber tais gastos como investimento, e sim como 


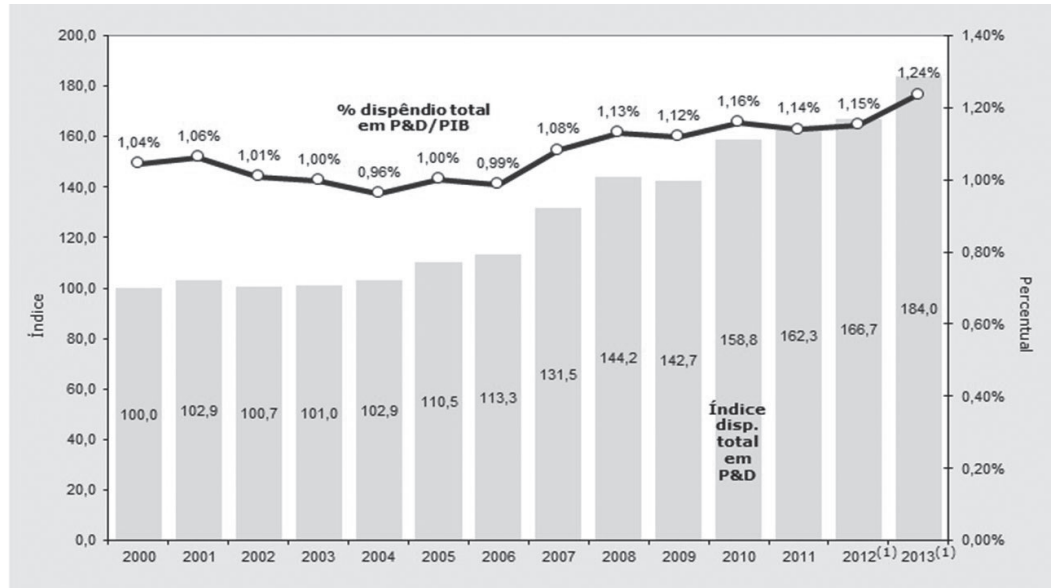

Figura 27.2 Relação de investimento em pesquisa e desenvolvimento pelo Estado e pela iniciativa privada no mundo. A grande diferença entre o Brasil e os outros países desses grupos é o volume de investimento em pesquisa e desenvolvimento feito pela iniciativa privada. 0 0,55\% do PIB aplicado pelas empresas brasileiras está longe dos 2,68\% investidos pelo setor privado da Coreia do Sul ou dos 1,22\% da China, por exemplo. Quando se comparam os investimentos públicos, no entanto, os gastos do Brasil estão na média das nações mais desenvolvidas: 0 0,61\% do PIB brasileiro está próximo do percentual investido pelo conjunto dos países da Organização para Cooperação e Desenvolvimento Econômico (OCDE)* $(0,69 \%)$.

despesas, tal qual ocorre com a educação no país. Além do mais, o governo não atualizou os números correspondentes aos anos em que houve a pior crise desde o início da década de 1990.

Um dos gargalos é a promoção da inovação nas empresas. A promoção da inovação no setor produtivo é um dos pilares da Estratégia Nacional de Ciência, Tecnologia e Inovação (ENCTI). No Brasil, em 2013, 40,3\%, do gasto em P\&D é feito pelas empresas, enquanto em vários dos países mais dinâmicos tecnologicamente (Estados Unidos, Alemanha, China, Coreia do Sul e Japão) essa proporção está perto de $75 \%$, e o montante investido é sempre quase o triplo ou o quádruplo do brasileiro (Figura 27.5), o que demonstra que a participação do setor empresarial nos esforços tecnológicos brasileiros ainda está aquém dos níveis observados internacionalmente. Em 2011, a participação de empresas correspondia a 45,7\%.

* Organização para Cooperação e Desenvolvimento Econômico (OCDE): organização internacional com 34 países que aceitam os princípios da democracia representativa e da economia de livre mercado. Os membros têm economias de alta renda e alto IDH e são considerados países desenvolvidos, exceto México, Chile e Turquia. Teve origem em 1948 para ajudar a administrar o Plano Marshall para a reconstrução da Europa após a Segunda Guerra Mundial. 


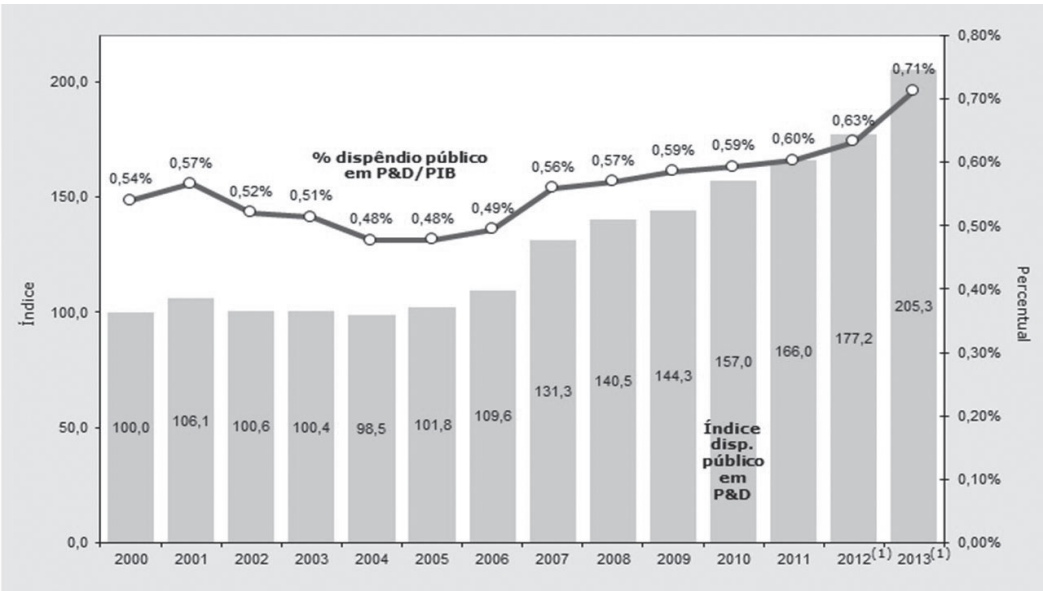

Figura 27.3 Brasil: Comparação entre o índice real de crescimento do dispêndio total em pesquisa e desenvolvimento (P\&D) e 0 percentual do dispêndio total em relação ao PIB, 2000-2013.

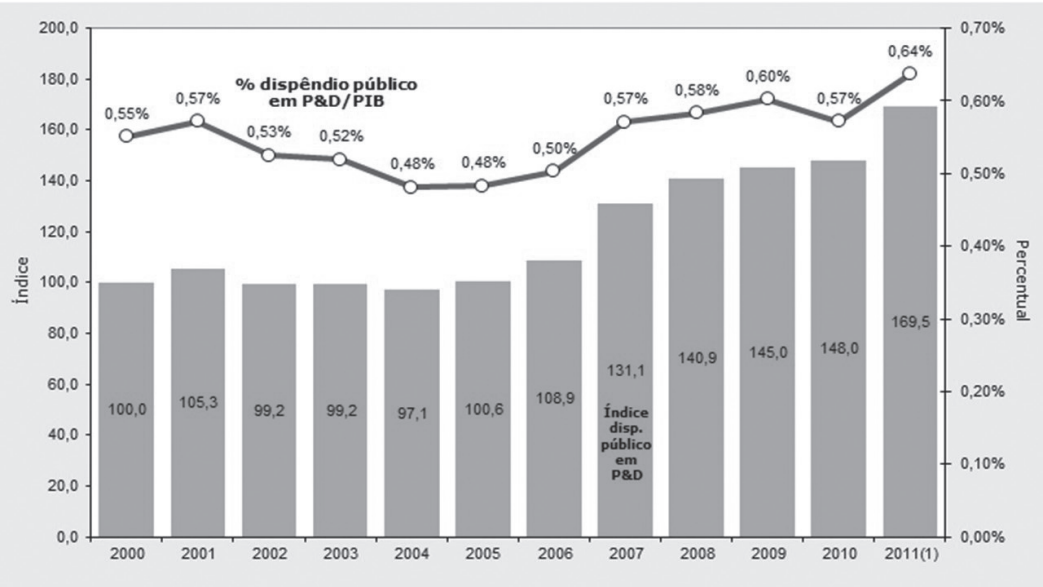

Figura 27.4 Brasil: Comparação entre o índice real de crescimento do dispêndio público em pesquisa e desenvolvimento (P\&D) e 0 percentual do dispêndio público em relação ao PIB, 2000-2011.

Agrava-se a situação porque, historicamente, boa parte das inovações realizadas pelo setor produtivo brasileiro está relacionada a inovações de processo - majoritariamente baseadas na aquisição de tecnologias incorporadas em máquinas e equipamentos - ou a inovações adaptativas. Embora a taxa 
de inovação na indústria (número de empresas inovadoras em relação ao total) tenha crescido de $33,4 \%$, para $38,1 \%$ entre 2005 e 2008 , apenas $4,1 \%$ das empresas industriais criaram um produto efetivamente novo, ou substancialmente aperfeiçoado, para o mercado nacional. Esse comportamento adaptativo está associado ao baixo investimento em P\&D do setor empresarial brasileiro, uma vez que esse tipo de inovação requer menores esforços tecnológicos e implica em número extremamente baixo de pesquisadores que exercem atividades no âmbito das empresas, quando comparado com outros países. No Brasil, a maior parte dos pesquisadores está nas instituições de ensino superior - $67,5 \%$ do total em 2010 -, enquanto nas empresas essa proporção é de apenas $26,2 \%$, bastante abaixo dos índices de países como Estados Unidos, Coreia do Sul, Japão, China, Alemanha, França e Rússiaa ${ }^{15}$.

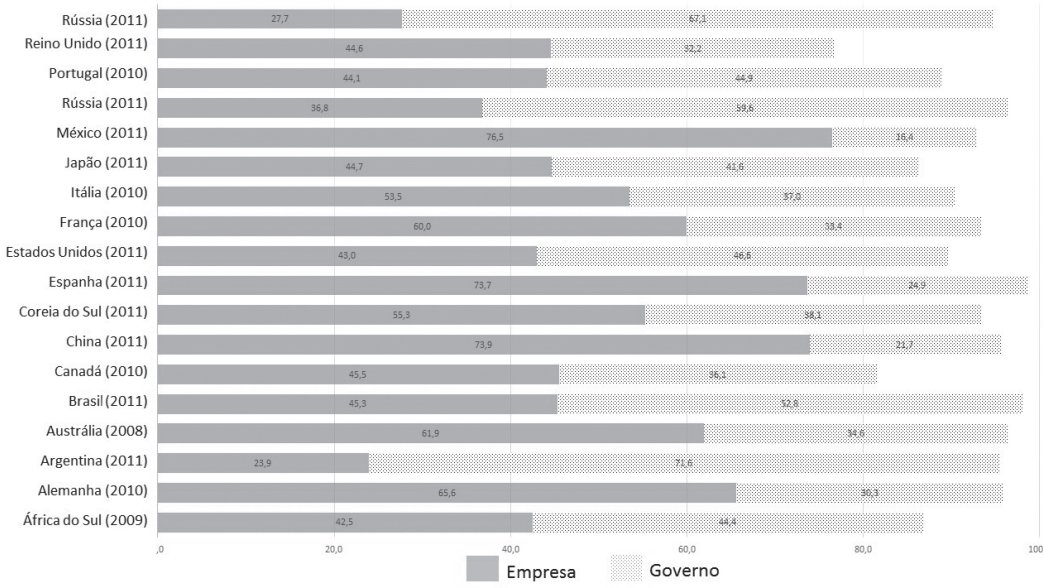

Figura 27.5 Distribuição percentual dos dispêndios nacionais em pesquisa e desenvolvimento (P\&D), segundo setor de financiamento, países selecionados, 2012-201315. Notas: 1) Os percentuais não somam 100\% porque foram considerados apenas os setores de maior relevância, governo e empresas. Não foram considerados os demais setores: ensino superior, instituições privadas sem fins de lucro e estrangeiro. 2) não foi considerada a pós-graduação do setor empresas. 3) no setor Governo inclui empresas estatais.

O que faz uma nação tão pequena em território geográfico ser assim exponencial em inovação? Como nos Estados Unidos, Israel faz das universidades muito mais que instituições empreendedoras: tem em seus funcionários e alunos uma cultura empreendedora. Os professores comandam laboratórios como se fossem seu próprio negócio, e os alunos são incentivados a criar suas start-ups. No entanto, no Brasil, ainda não há muito incentivo 
para essas questões nas universidades. Primeiro, não há divisão entre professores de ensino e professores cientistas, ou seja, um mesmo professor precisa exercer ambas as funções. Em segundo, não há meritocracia na progressão, que depende fundamentalmente do tempo de trabalho. E em terceiro, criando-se um produto inovador, é preciso solicitar que a universidade faça o pedido de depósito da patente, o que leva meses. Se o professor arriscar-se a fazer o depósito por si mesmo, pode ser processado por roubo de propriedade privada do governo, mesmo tendo sido o inventor. Um professor em regime de dedicação exclusiva em uma universidade pública não pode, por contrato, abrir uma empresa. Já em Israel e nos Estados Unidos, ocorre o contrário: o professor é até incentivado.

A Tabela 27.5 apresenta ainda a proporção da população envolvida em pesquisa no Brasil. Para efeito de comparação, apresenta-se também o número de pessoas ocupadas em cada país.

Tabela 27.5 Pesquisadores em pesquisa e desenvolvimento (P\&D), em equivalência de tempo integral, de países selecionados (20002013, em pesquisadores por mil pessoas ocupadas)

\begin{tabular}{ccccccccccccccc} 
PAís & 2000 & 2001 & 2002 & 2003 & 2004 & 2005 & 2006 & 2007 & 2008 & 2009 & 2010 & 2011 & 2012 & 2013 \\
\hline África do Sul & - & 1,2 & - & 1,2 & 1,5 & 1,4 & 1,4 & 1,4 & 1,3 & 1,4 & 1,4 & 1,4 & 1,5 & - \\
\hline Alemanha & 6,5 & 6,6 & 6,7 & 6,9 & 6,9 & 6,9 & 7,1 & 7,2 & 7,4 & 7,8 & 8,0 & 8,1 & 8,4 & 8,5 \\
\hline Argentina & 2,0 & 2,0 & 2,0 & 2,0 & 1,9 & 2,0 & 2,2 & 2,3 & 2,5 & 2,6 & 2,8 & 2,9 & 2,9 & 2,9 \\
\hline Austrália & 7,3 & - & 7,8 & - & 8,3 & - & 8,5 & - & 8,6 & - & - & - & - & - \\
\hline BRASIL & - & 1,0 & 1,0 & 1,1 & 1,2 & 1,3 & 1,3 & 1,3 & 1,3 & 1,4 & - & - & - & - \\
\hline Canadá & 7,1 & 7,5 & 7,4 & 7,7 & 8,0 & 8,3 & 8,4 & 8,9 & 9,0 & 8,8 & 9,1 & 9,2 & 8,8 & - \\
\hline China & 1,0 & 1,0 & 1,1 & 1,2 & 1,2 & 1,5 & 1,6 & 1,9 & 2,1 & 1,5 & 1,6 & 1,7 & 1,8 & 1,9 \\
\hline Cingapura & 7,7 & 7,7 & 8,4 & 9,4 & 9,7 & 10,3 & 10,0 & 10,0 & 9,4 & 10,2 & 10,3 & 10,4 & 10,2 & - \\
\hline Coreia do Sul & 5,1 & 6,3 & 6,4 & 6,8 & 6,9 & 7,9 & 8,6 & 9,5 & 10,0 & 10,4 & 11,1 & 11,9 & 12,8 & 12,8 \\
\hline Espanha & 4,6 & 4,6 & 4,7 & 5,1 & 5,3 & 5,5 & 5,6 & 5,8 & 6,1 & 6,7 & 6,9 & 6,8 & 6,9 & 6,9 \\
\hline Estados Unidos & 7,1 & 7,3 & 7,5 & 8,0 & 7,8 & 7,6 & 7,7 & 7,6 & 8,1 & 8,8 & 8,5 & 8,8 & 8,7 & - \\
\hline França & 6,7 & 6,8 & 7,1 & 7,4 & 7,7 & 7,7 & 7,9 & 8,2 & 8,4 & 8,7 & 9,1 & 9,2 & 9,6 & 9,8 \\
\hline Itália & 2,9 & 2,8 & 3,0 & 2,9 & 3,0 & 3,4 & 3,5 & 3,7 & 3,8 & 4,1 & 4,2 & 4,3 & 4,5 & 4,9 \\
\hline Japão & 9,9 & 10,0 & 9,7 & 10,1 & 10,0 & 10,4 & 10,4 & 10,4 & 10,0 & 10,1 & 10,2 & 10,2 & 10,0 & 10,2 \\
\hline México & - & 0,6 & 0,8 & 0,9 & 1,0 & 1,1 & 0,9 & 0,9 & 0,9 & 1,0 & 0,8 & 0,8 & - & - \\
\hline Portugal & 3,3 & 3,5 & 3,7 & 4,0 & 4,1 & 4,2 & 4,9 & 5,6 & 8,0 & 8,1 & 8,5 & 9,2 & 9,3 & 9,7 \\
\hline Reino Unido & 6,2 & 6,5 & 7,1 & 7,7 & 8,0 & 8,6 & 8,7 & 8,6 & 8,5 & 8,8 & 8,8 & 8,6 & 8,7 & 8,7 \\
\hline Rússia & 7,8 & 7,8 & 7,4 & 7,3 & 7,1 & 6,8 & 6,7 & 6,6 & 6,4 & 6,4 & 6,3 & 6,3 & 6,2 & 6,2 \\
\hline
\end{tabular}

Fonte: Organisation for Economic Co-operation and Development, Main Science and Technology Indicators, 2015/1 e Brasil: Coordenação-Geral de Indicadores (CGIN) - ASCAV/SEXEC - Ministério da Ciência, Tecnologia e Inovação (MCTI) ${ }^{16}$. 
A economia do Vale do Silício, onde estão as grandes empresas americanas de internet e a Universidade Stanford, tem sido um dos principais motores da recuperação americana: tem crescido o dobro da média nacional. Apesar de existirem no Brasil algumas poucas iniciativas entre o setor privado e as instituições de ensino, ainda há muita resistência a esse tipo de cooperação.

Existe no Brasil um misto de ausência de conhecimento sobre o setor privado com preconceito contra o capitalismo. Atualmente, a maioria dos professores que ocupam posição de chefia ainda remoem os anos da ditadura com uma dose de comunismo para todos, exceto para quem está no comando.

A inovação que é desenvolvida em Israel é classificada como sendo uma inovação disruptiva, ou radical, do tipo que cria novos nichos de mercados ao contrário da inovação incremental, que melhora tecnologias previamente existentes.

As inovações disruptivas são as responsáveis pelo crescimento alavancado de nações com rendas acima da média ou alta renda, já que criam novos mercados, possibilitando que outros países pobres comprem suas novidades. Como mostra o exemplo israelense, o caminho da inovação é longo, mas costuma ser recompensador.

\subsection{ENSINO SUPERIOR}

\section{Problema apresentado pelo Brasil}

O Brasil forma profissionais de áreas ligadas à infraestrutura, como engenheiros; profissionais das áreas humanas, como administradores e economistas; e profissionais da área de saúde com muita pouca qualidade, tanto para sustentar o avanço da economia quanto para promover o bem necessário à população.

\section{Exemplo a ser seguido}

Japão. 


\section{Solução para o desenvolvimento do Brasil}

Como ensina a história das nações que se tornaram ricas nas últimas décadas, uma condição fundamental para o aumento do nível de renda da população acima de um patamar médio é a necessidade de se ter mão de obra qualificada, com formação sólida em universidades de qualidade, que não se resuma ao número de graduados e de fato possua conhecimento para aplicação prática. Um exemplo clássico é o Japão.

Essa nação saiu da Segunda Guerra Mundial empobrecida, quebrada e destruída, tanto em infraestrutura (lembremos das duas bombas atômicas lançadas sobre importantes centros comerciais) quanto em termos populacionais. Seu PIB por habitante não passava de 3 mil dólares, valores atualizados. Contudo, o sentimento de nação de seu povo ultrapassava o âmbito político: a própria sociedade, construída com base em uma cultura de respeito, disciplina e meritocracia, soube aplicar os investimentos estrangeiros para ajudar na sua reconstrução do país.

Divisão de trabalho e foco em duas metas essenciais para a reconstrução da nação foram seguidas: inovação industrial e formação de engenheiros sendo que a primeira dependeria do sucesso da segunda. O resultado foi a posição de vanguarda tecnológica do Japão em pouco mais de uma década.

Reflexos dessa política persistem até hoje: quase $20 \%$ dos jovens japoneses que se formam nas universidades escolheram a engenharia como carreira. Já no Brasil, essa participação é de 11,4\%.

Os programas REUNI e PROUNI vieram com o objetivo de reduzir a demanda represada no Ensino Médio, e a intenção era aumentar o número de graduados no Brasil. Embora tenha havido um acréscimo impressionante no número de graduandos no país (ver discussão adiante), a qualidade foi deixada de lado. Os alunos que concluem o Ensino Médio não podem ser reprovados; consequentemente, são aprovados sem ter o mínimo conhecimento necessário para prosseguir seus estudos no Ensino Superior. A implementação do ENEM praticamente obrigou as universidades públicas federais a aceitarem seu modo de funcionamento e realização, caso contrário a verba destinada à instituição para ampliação e melhoria de suas instalações seria retida pelo governo federal.

O Brasil está entre os países que mais reduziram o número de estudantes na faixa de 15 anos com baixo rendimento em matemática no período de 2003 a $2012^{17}$. Conforme dados divulgados pela Organização para Cooperação e Desenvolvimento Econômico (OCDE), a Alemanha, a Itália, o México e Portugal também estão nesta lista. 
Um relatório publicado pela OCDE recomenda que, para ampliar os ganhos de rendimento dos estudantes, os países aumentem o acesso à educação na infância, a oferta de atividades diferenciadas para alunos com dificuldades e o incentivo à participação dos pais e da comunidade na vida escolar ${ }^{17}$.

O relatório traz uma nova análise do Programa Internacional de Avaliação de Alunos (Pisa), divulgado em 2013, mas com dados referentes a 2012. O estudo "Alunos de baixo desempenho: por que ficam para trás e como ajudá-los?” examina o baixo desempenho na escola olhando para a família, práticas escolares, políticas educacionais entre outros fatores ${ }^{17}$.

Apesar da melhora em relação aos conhecimentos básicos, os alunos brasileiros ficaram apenas no $58^{\circ}$ lugar em matemática entre os 65 países e territórios analisados no último estudo do Pisa. Com essa classificação, o Brasil se situa abaixo da Albânia e da Costa Rica.

A organização considera que os alunos que ficam abaixo do nível 2 (entre os seis existentes, que evoluem de acordo com o grau de dificuldade das perguntas) nas disciplinas analisadas (matemática, leitura e ciências) terão dificuldades na escola e, mais tarde, no mercado de trabalho, e poderão não ascender socialmente.

Segundo o Pisa, 67,1\% dos alunos brasileiros com 15 e 16 anos (faixa etária analisada no estudo) estão abaixo do nível 2 em matemática, com baixa performance na disciplina. Apenas $0,8 \%$ dos alunos brasileiros atingiram os níveis 5 e 6 na disciplina, que exigem análises complexas. Em Xangai, na China, primeiro do ranking em matemática, mais da metade dos estudantes $(55,4 \%)$ integram os níveis 5 e 6 , de alta performance.

Em matemática, a média dos países da OCDE é de 494 pontos. Essa mesma instituição destaca que o Brasil registrou uma das maiores taxas de crescimento no total de pontos em matemática entre 2003 a 2012, passando de 356 a 391 pontos no período.

\subsubsection{Matrículas na educação}

De acordo com dados do último censo da Educação Básica do Inep/MEC de 2012, existem no Brasil 8.376.852 alunos matriculados no Ensino Médio. Já o Ensino Médio técnico conta com pouco mais de 1,3 milhão de alunos em todo o país.

No Ensino Superior, segundo o mesmo censo, temos 7.037 .688 alunos. Destes, 5.923 .838 são alunos de cursos presenciais (um crescimento de 3,1\% 
em relação ao ano de 2011) e 1.113 .850 de educação a distância (aumento de $12,2 \%$ no mesmo período).

Em 2012, 11.957 .756 candidatos inscreveram-se para vestibulares, mas apenas 4.653.756 vagas foram oferecidas. Desses quase 12 milhões de pessoas, 6.738.819 candidataram-se para universidades públicas, enquanto 5.218 .937 escolheram as particulares. Infelizmente, somente $23 \%$ desses quase 12 milhões (2.747.089) conquistaram o sonho de entrar em uma faculdade. Ou seja, 9.210 .667 não tiveram acesso à educação superior naquele ano.

Dos quase 7 milhões em busca de uma oportunidade em escolas federais, estaduais e municipais, apenas $8 \%$ são aprovados (547.897). Nas privadas, a porcentagem sobe para $42 \%(2.199 .192)$ dos pouco mais de 5 milhões inscritos. Do total de ingressantes, 20\% (547.897) vão para uma instituição de ensino pública, enquanto $80 \%(2.199 .192)$ a uma particular.

Com relação à pós-graduação, temos no Brasil 203.717 mil alunos. Ou seja, apenas $2,9 \%$ em relação ao índice de estudantes da graduação. No entanto, houve um aumento de 8,5\% em relação ao último censo de 2011. Um alerta aqui deve ser dado: os únicos programas de pós-graduação com controle de números são os de mestrado e doutorado e, em 2014, os de pós-doutorados, o que significa que sobre os de especialização o Ministério da Educação não tem qualquer controle.

\subsubsection{Ensino Superior}

De 2002 a 2012, o número de alunos na educação superior dobrou, passando de 3,5 milhões para 7 milhões. Já o total de concluintes deu um salto de $119 \%$, passando de 479.275 para 1.050 .413 . É importante ressaltar o número de licenciados com o diploma na mão: 130.790 (12,5\% do número total de formados), podendo exercer o cargo de professor no Ensino Médio.

Os ingressantes também evoluíram 87,4\% em 2012: atualmente, 2.747.089 entram no Ensino Superior, contra 1.465.605, há dez anos. São 31.866 cursos de graduação, distribuídos em 2.416 instituições (304 públicas e 2.112 particulares).

Apesar do avanço no número de formandos, apenas $38 \%$ dos calouros concluem o curso superior, sendo 237.546 no setor público e 812.867 no privado. Grande parte desses estudantes não conclui ou abandona o curso, provavelmente por falta de condições financeiras. Esses números provam a importância do estágio, pois ele ajuda o futuro profissional a custear seu 
curso. Afinal, para estagiar, o jovem obrigatoriamente precisa estar regularmente matriculado.

Dos mais de 7 milhões de jovens universitários, 67,1\% optaram pelo bacharelado, enquanto $19,5 \%$ fazem licenciatura e 13,5\% são tecnólogos. Cerca de $5.140 .312(73 \%)$ estão na universidade particular e 1.897 .413 $(27 \%)$ na pública. No total, 31.866 cursos diferentes são oferecidos no Brasil.

\subsubsection{Qualidade}

A questão da falta de qualidade é demonstrada pelo fato de que na lista das 200 melhores universidades do mundo não há nenhuma brasileira. A deficiência se reflete no desempenho dos formados no país.

Uma pesquisa recente da consultoria McKinsey \& Company avaliou o desempenho dos engenheiros em 83 multinacionais que atuam em países emergentes, e mostra que apenas 13 em cada 100 engenheiros brasileiros têm formação considerada adequada para a área em que atuam ${ }^{12}$. $\mathrm{Na}$ Hungria, o melhor entre os emergentes, esse número é de $50 \%$. A defasagem não se limita à engenharia. O mesmo se dá, na mesma proporção, com profissionais de finanças e contabilidade.

Para os economistas, a situação do Brasil em relação à formação de engenheiros - elemento básico no motor de desenvolvimento de um país - tem um impacto considerável na produtividade média do trabalhador brasileiro. A produtividade no Brasil está estagnada há três décadas: nosso produto per capita de 20 mil dólares por ano é um quarto do produto per capita japonês.

Nos últimos anos, o Brasil evoluiu consideravelmente na oferta de cursos de ensino superior - em 2013, cerca de $20 \%$ dos brasileiros entre 18 e 24 anos de idade tinham acesso à universidade, 120\% mais do que em 2000. Os números mostram que o avanço da qualidade desses cursos, no entanto, não ocorreu na mesma velocidade. Eis o desafio do Brasil para os próximos anos - e décadas.

Um relatório produzido pela empresa de sistemas de aprendizado Pearson (ligada ao jornal britânico Financial Times) e pela consultoria britânica Economist Intelligence Unit (EIU) exibe um ranking que compara resultados de provas de matemática, ciência e leitura e índices como taxa de alfabetização e aprovação escolar, no qual, em 2012, o Brasil ficou em penúltimo lugar. Em 2014, o Brasil distanciou-se ainda mais das médias dos 40 países estudados, mas, apesar de seu índice ter piorado, subiu uma posição 
no ranking - de penúltimo para antepenúltimo -, mas isso se deveu a uma queda acentuada do México, e não a uma melhora na situação do Brasil. Assim, em 2014, o Brasil aparece na $38^{a}$ posição do ranking, apenas à frente de México e Indonésia.

O indicador do ranking é composto a partir de duas variáveis: capacidade cognitiva (medida por resultados de alunos nos testes internacionais PISA, TIMSS e PIRLS) e sucesso escolar (índices de alfabetização e aprovação escolar). Note-se aqui que nem mesmo a aprovação escolar obrigatória (já que atualmente no Brasil não há reprovação, por vários motivos que não abordaremos) resolve o problema de posicionamento no ranking. Embora eficiente para as estatísticas, a política de não reprovação leva a um péssimo rendimento e aprendizagem escolar. Está aí uma boa oportunidade para mudar o atual sistema de aprovação no ensino!

O número usado para comparar os países ("score z") indica quão longe cada nação está da média dos 40 países (que é zero, nessa escala). Foram analisadas nações da Ásia, da Europa e das Américas - nenhum país africano participa do ranking.

No estudo de 2012, o score obtido pelo Brasil foi de -1,65; em 2014, o indicador piorou para $-1,73$, sendo que o sinal negativo indica que ambos os países estão abaixo da média dos 40 países. Isso demonstra que a atual política do "aprovar sem saber" distancia ainda mais o Brasil das nações desenvolvidas, fazendo com que o povo brasileiro se torne alienado e sem conhecimento e transformando o futuro do país num caos. Fato é que o país está mais distante da média dos 40 países. Já o México viu seu score cair de $-1,6$ para $-1,76$.

O Brasil piorou nas duas variáveis, tanto na capacidade cognitiva, leia-se de raciocínio (de $-2,01$ para $-2,06$ ), quanto no sucesso escolar (de $-0,94$ para -1,08).

É preciso fazer uma observação: como já dito, os valores dos scores apresentados são sempre comparados com a média das 40 nações. Sendo assim, não é possível determinar ao certo se a piora do indicador do Brasil se deve a uma queda no desempenho dos alunos brasileiros ou se houve uma melhora na média mundial. Independentemente disso, fato é que o país está entre os últimos colocados no quesito capacidade de raciocínio e entendimento. Uma questão séria, já que se a população lê um texto mas não o compreende, então ela pode ser considerada analfabeta funcional. 


\subsubsection{Mais professores de ciências e matemática}

Outra informação que se pode retirar do estudo é que os países em desenvolvimento estão posicionados na metade inferior do ranking. Como já dissemos, em 2014 a Indonésia aparece novamente em último lugar das 40 nações analisadas, precedida por México e Brasil.

O relatório também apresenta um capítulo com os modelos a serem seguidos pelos países em desenvolvimento. Um dos pontos é que o Brasil precisa de um aumento de $30 \%$ no número de professores de ciências e matemática para aliviar as pressões sob seu contingente, que está sobrecarregado e carece de treinamento e de conhecimento.

\subsection{5 Ásia em alta}

$\mathrm{Na}$ edição de 2014, houve uma reviravolta entre os primeiros colocados. No topo do ranking, a novidade dessa edição é a queda dos países escandinavos e a ascensão dos asiáticos.

No relatório de 2012, a Finlândia liderava o ranking, com score de 1,26 (valores positivos), descendo para 0,92 no relatório de 2014 - uma queda para a quinta posição, atrás de Coreia do Sul, Japão, Cingapura e Hong Kong. O relatório afirma que países escandinavos, como Suécia e Finlândia, têm visto nos últimos anos as notas de seus alunos piorarem nos testes internacionais. No caso da Finlândia, a explicação dada pelos próprios professores do país foi em relação ao ensino de matemática que tem sido deixado de lado, justamente onde houve a maior queda no índice da Finlândia. Os países asiáticos são exemplos de que a educação deve ser vista como um investimento de longo prazo, que, se aumentados os investimentos periodicamente, é capaz de elevar países em desenvolvimento à posição de nação rica.

\subsection{INSTITUIC̣õES SÓLIDAS}

\section{Problema apresentado pelo Brasil}

Um problema de base que dá sustentação à economia do país está em suas instituições, que carecem de credibilidade. 


\section{Exemplo a ser seguido}

Estados Unidos.

\section{Solução para o desenvolvimento do Brasil}

O exemplo escolhido é a cidade de Nogales, que é dividida por um muro separando uma cidade ao norte, localizada no estado norte-americano do Arizona, e uma ao sul, localizada no estado mexicano de Sonora. Embora a população tenha a mesma composição étnica e cultural, além das mesmas condições geoclimáticas, na cidade ao norte, nos EUA, a população tem acesso à educação, moradia e tem boa saúde, com cobertura de saneamento básico para todos os bairros. Sua renda per capita é de cerca de 30 mil dólares. Já na cidade ao sul, no México, a população carece de saúde, educação e saneamento básico. A população jovem em idade escolar não está matriculada em escolas, o que acarreta uma alta taxa de criminalidade. Sua renda per capita é um terço menor que a da cidade ao norte.

O que faz uma mesma cidade, na mesma região geográfica e com o mesmo povo apresentar diferenças sociais tão acentuadas? As diferenças entre as duas cidades são suas instituições ${ }^{18}$. Acemoglu, professor no Massachusetts Institute of Technology (MIT), e Robinson, professor da Universidade de Harvard, fazem uma demonstração cabal de que são as instituições políticas e econômicas que estão por trás do êxito econômico (ou da falta dele). Eles afirmam que os países só escapam à pobreza quando dispõem de instituições econômicas adequadas, sobretudo a propriedade privada e a concorrência. São elas que dão forma aos incentivos para as decisões de investimento - em infraestrutura, na formação da mão de obra, em máquinas e na inovação. As instituições são, em resumo, o alicerce sem o qual nenhuma estrutura crucial para o crescimento consegue ficar de pé.

Quando estudamos a história do Brasil a partir de 2010, verificamos que houve um retrocesso nessa área. O início do Plano Real, em 1994, fez com que o Banco Central se tornasse uma instituição firme, mas, desde meados de 2010, sua reputação como guardião da moeda tem caído, por exemplo, com a alta da inflação. A credibilidade do Tesouro Nacional como gerente das contas públicas foi corroída por manobras que encobrem gastos. A Petrobras, a maior empresa nacional, teve uma queda vertiginosa, perdendo mais de 400 posições ${ }^{19}$. A estatal brasileira, que é uma empresa de economia mista, sendo $49 \%$ privada e $51 \%$ pública, saiu da $12^{a}$ posição de maior 
valor de mercado mundial, em 2009, para a 416 , em $2015^{19}$. Em 2013, era a $20^{a 19}$. Um círculo vicioso e ocioso de uso da máquina pública para encobrir gastos, controlar a inflação e alocar apadrinhados políticos como gestores em setores que movimentam volumosos recursos financeiros.

O setor público consolidado - governos federal, estaduais e municipais e empresas estatais - registrou superávit primário de 91,306 bilhões de reais em 2013. O superávit primário corresponde à economia de recursos para pagar os juros da dívida pública e reduzir o endividamento do governo no médio e longo prazos. O resultado de 2013 correspondeu a 1,9\% de tudo o que o país produziu, ou seja, o PIB. Trata-se do menor nível anual da série histórica do Banco Central (BC), iniciada em dezembro de 2001. Em 2012, o superávit primário ficou em 104,951 bilhões de reais, o que correspondeu a 2,39\% do PIB. Em 2014, o país registrou déficit primário de 32,536 bilhões de reais, o primeiro resultado negativo desde o início da série histórica, em 2001. Com isso, o saldo primário negativo foi equivalente a $0,63 \%$ do Produto Interno Bruto (PIB), também o pior já registrado. E em 2015, o déficit primário recorde foi de $\mathrm{R} \$ 111,249$ bilhões ou 1,88\% do Produto Interno Bruto (PIB).

A economia brasileira encolheu 3,8\% em 2015 na comparação com 2014, segundo os dados do PIB (Produto Interno Bruto) divulgados pelo IBGE (Instituto Brasileiro de Geografia e Estatística).

Essa é a maior queda desde que a atual pesquisa do IBGE começou a ser feita, em 1996. Se forem considerados os dados anteriores do PIB, que começam em 1948, é o pior resultado em 25 anos, desde 1990 (-4,3\%), quando Fernando Collor de Mello assumiu o governo e decretou o confisco da poupança.

Esta é a sétima vez que o Brasil tem PIB negativo desde 1948: 1981 (-4,3\%), 1983 (-2,9\%), 1988 (-0,1\%), 1990 (-4,3\%), 1992 (-0,5\%), 2009 $(-0,1 \%)$ e, agora, $2015(-3,8 \%)$.

Em valores correntes, o PIB de 2015 ficou em 5,9 trilhões de reais. O PIB per capita ficou em 28.876 reais em 2015, com queda de 4,6\% em relação ao ano anterior.

Originalmente, a Lei de Diretrizes Orçamentárias (LDO) previa meta de superávit primário de $3,1 \%$ do PIB para a União, estados e municípios em 2013. Depois, o governo lançou mão de mecanismos que permitiam o abatimento de gastos do Programa de Aceleração do Crescimento (PAC) e de receitas que deixaram de entrar na conta por causa de desonerações, revisando a meta para 2,3\% do PIB (110,9 bilhões de reais). E, no fim de novembro de 2013, foi aprovada emenda à LDO que desobrigava a União 
de compensar o descumprimento da meta dos governos estaduais e das prefeituras. A meta somente do governo central, que correspondia a 108,09 bilhões de reais, foi reduzida para 73 bilhões de reais. Todas essas reduções são interpretadas pelo mercado como falta de compromisso e seriedade, refletindo-se diretamente na descrença do Brasil como atrativo para investidores externos. Esses dados demonstram apenas o início de uma série de ações tomadas pelo governo federal atual, culminando em interrupções dos investimentos interno e externos.

Portanto, no que diz respeito ao arcabouço institucional, perdemos parte do que havíamos conquistado em duas décadas.

Quais são os critérios usados para definir o tamanho e o destino dos empréstimos dos bancos públicos? Uma instituição que usa dinheiro público tem de prestar contas à sociedade. Em 2012, houve um incêndio em um hotel em Nogales, México, e bombeiros americanos foram chamados. No caso das instituições econômicas brasileiras, quem vai apagar o fogo?

\subsection{INCENTIVO NAS UNIVERSIDADES: DAS IDEIAS AOS NEGÓCIOS}

\section{Problema apresentado pelo Brasil}

As universidades brasileiras não possuem estrutura para criar start-ups, e as que tentam construir essa estrutura não investem nas ideias certas que gerariam negócios.

\section{Exemplo a ser seguido}

Estados Unidos.

\section{Solução para o desenvolvimento do Brasil}

Dentre as universidades americanas de destaque e que estão envolvidas no assunto inovação de longa data estão a Universidade de Stanford e o Massachusetts Institute of Technology (MIT) que, ainda nos anos 1970, criaram os primeiros escritórios de gerenciamento de patentes dentro de universidades, 
responsáveis por cuidar da burocracia necessária para licenciar as tecnologias e, principalmente, levá-las ao mercado. Descobrir o próximo Google é uma boa forma de conseguir prestígio, atrair bons alunos e ganhar dinheiro.

A Universidade de Stanford, onde o buscador Google foi criado, obteve só com o licenciamento do código do software 337 milhões de dólares. Em 2012, somente em receitas geradas pelo licenciamento e royalties por patentes, as universidades americanas receberam 2,6 bilhões de dólares. Desse montante, a Universidade de Nova York (NYU) foi a que teve o maior faturamento, com 185 milhões de dólares.

A estratégia adotada pela NYU foi incluir, dentre as obrigações do escritório de patentes, o casamento entre as invenções que têm potencial para se transformar em negócios ou em tecnologias para a indústria com as empresas interessadas na sua produção e comercialização. Um papel ativo, não de mero setor burocrático à espera da efetivação de uma parceria.

Por meio de um sistema meritocrático e de recompensas, em 2013, $60 \%$ das patentes licenciadas pela NYU foram comercializadas, um dos índices mais altos dos Estados Unidos. A universidade também criou $87 \%$ mais start-ups por dólar investido do que a média das universidades norte-americanas.

A também norte-americana Universidade de Harvard é um exemplo de fenômeno que ocorre nos escritórios de transferência de tecnologia de universidades. Esses escritórios executam as tarefas de rotina, que consistem em identificar pesquisas com potencial de gerar dividendos para a universidade e para os pesquisadores envolvidos, redigem e fazem os pedidos de patentes para protegê-las, assim como fomentam e buscam firmar colaborações de pesquisa de longo prazo entre empresas e os laboratórios de pesquisa da universidade. Eles também auxiliam aos pesquisadores líderes de grupo e seus alunos na criação de empresas baseadas em tecnologias inovadoras, fazem a busca pelos investidores do setor privado para financiá-las, ofertam consultorias de cientistas especializados para setores industriais específicos, além de impulsionar o empreendedorismo entre os alunos de graduação e pós-graduação ligados aos laboratórios de pesquisa dos professores da universidade. Os dados mostrados pela Universidade de Harvard, dentre outras universidades norte-americanas, demonstram que é factível obter resultados positivos tanto para as empresas quanto para as universidades e seus pesquisadores, independentemente de suas questões culturais e objetivos socioeconômicos, desde que haja um compromisso com parcerias em que ambos os lados saem ganhando. 
Em Harvard, um dos pontos-chave para a exequibilidade desses escritórios que fazem a ponte entre os professores e os interesses das empresas foi a criação do Fundo Acelerador de Desenvolvimento Tecnológico. Esse fundo recebe recursos de doadores privados, alguns ex-alunos de sucesso empresarial, como Mark Zuckerberg, o fundador do Facebook - que antes, quando aluno, não possuía recursos para financiar suas ideias -, com o intuito de impulsionar o desenvolvimento de tecnologias ainda em estágio embrionário e possibilitar que essas tecnologias possam vir a ser um produto licenciado comercializado. Esse fundo fornece os recursos para a condução de pesquisas entre a fase posterior à descoberta e anterior à comercialização, comumente chamados de experimentos para gerarem provas de conceito, que definem se a tecnologia será útil para a sociedade e se terá demanda, aumentando a possibilidade de uma empresa se interessar pela tecnologia e efetuar sua compra.

Outra universidade de sucesso na condução das ideias dos pesquisadores para as prateleiras do comércio é a Universidade da Califórnia (UC), em Berkeley. Em 1990, a UC criou seu Escritório de Licenciamento de Tecnologia, influenciada pela Lei Bayh-Dole, de 1980, que assegurou às instituições de pesquisa norte-americanas o direito de patentear descobertas feitas com investimentos federais em pesquisa e licenciá-las para empresas. Engana-se quem pensa que os recursos públicos estariam sendo usados para interesses próprios porque, além de a pesquisa gerar benefícios diretamente para a sociedade, também gera novas oportunidades de emprego, novos mercados econômicos, além de impulsionar a economia e impostos para o governo. Um dos fatos que possibilitou o sucesso de sua atuação foi a criação do Ipira, sigla para Escritório de Propriedade Intelectual e Alianças de Pesquisa com a Indústria, em 2004. Além de fornecer o espaço físico e uma infraestrutura tecnológica básica para as start-ups operarem - o que costuma ser o padrão das universidades -, a incubadora passou a oferecer consultoria de professores e a fazer a conexão das empresas com os investidores. O Ipira executa os caminhos necessários para a proteção da propriedade intelectual das descobertas de seus pesquisadores, realizada por pessoal especializado, e a missão de busca de parceiros privados para a pesquisa na instituição, possibilitando a formação e execução de projetos patrocinados e o licenciamento pelas próprias empresas financiadoras das tecnologias que possam vir a surgir. Sempre, porém, pensando na parceria em longo prazo.

A UC hoje tem cinco incubadoras, que custaram 600 milhões de dólares. Em 2013, a universidade lançou 55 start-ups, o maior número entre as instituições americanas. As incubadoras são direcionadas para o setor de 
biotecnologia, no qual está presente o maior potencial de desenvolvimentos de produtos que possam vir a ser utilizados pela sociedade.

$\mathrm{Na}$ Inglaterra, a Universidade de Oxford é um modelo no quesito empresarial. Criou uma empresa para realizar a efetivação de parcerias entre indústrias e pesquisadores da universidade, além de oferecer sua expertise para outras universidades e empresas de vários países na forma de serviços e consultorias. Claro que toda empresa precisa de financiamento inicial, e a Universidade de Oxford efetuou um investimento inicial de 2,5 milhões de libras esterlinas, em 2011, numa empresa batizada de Isis Innovation. Todo bom investimento tem retorno em longo prazo (nesse caso, o longo prazo foi de apenas 3 anos); quando se alia eficiência com eficácia, o retorno chegou a 4 bilhões de libras esterlinas, na forma de royalties e venda de participação em empresas. A Isis Innovation, de Oxford, atua em três frentes, que faltam às incubadoras de empresas das universidades brasileiras. A primeira é o papel de proteção intelectual, realizada de maneira rápida e por profissionais qualificados, para que, em seguida seja feita a busca por indústrias interessadas no licenciamento da patente. Em média, a Isis registra uma patente por semana. No ano de 2012, a Isis gerenciava em torno de 400 patentes e um portfólio de 200 licenças de comercialização de tecnologias. A ponte entre o pesquisador e as empresas interessadas é importante e não pode deixar o primeiro de fora, já que são as suas ideias que são transformadas em produtos. Não se deve descartar os geradores do conhecimento após a venda de suas tecnologias. O papel da empresa de Oxford é auxiliar os pesquisadores na efetivação do negócio com a empresa, lembrando à universidade dos benefícios gerados à sociedade, comentados anteriormente. Outra frente abordada pela Isis é o oferecimento de consultoria de pesquisadores de Oxford a empresas e órgãos públicos. Em um primeiro momento o leitor poderia dizer que seria estranho uma instituição pública brasileira oferecer consultoria para outro órgão público, mas é preciso lembrar que os serviços prestados são referentes à instituição à qual tal pesquisador está vinculado. Por exemplo, um professor de uma universidade federal não sairá prendendo político por desvio de verba pública, que é papel da polícia federal. A terceira frente está focada em auxiliar, por meio de consultorias, instituições de diversos países (dados de 2012 contavam com 30 países diferentes) a comercializarem suas invenções. São exemplos acordos firmados com instituições de pesquisa da Rússia e da Espanha, em cujos parques científicos a Universidade de Oxford abriu um escritório para auxiliar as empresas daqueles países a comercializar as tecnologias desenvolvidas em suas universidades. 


\subsubsection{Estímulo à competição}

A criação de centros de empreendedorismo, mais do que um setor burocrático que visa apenas dar entrada em processos de pedidos de patentes, é um dos passos necessários para as universidades que querem copiar Stanford e o MIT. Além de todo o processo de pedido de patente e contatos com empresas interessadas em potenciais produtos desenvolvidos, esse centro organizaria eventos com a participação de empresários e ex-alunos que construíram suas próprias empresas para contar suas experiências como empreendedores. Afinal, nada melhor do que seguir modelos de negócios que deram certo. Nessa mesma linha de incentivo ao empreendedorismo, o centro promove competições que premiam as ideias mais promissoras dos estudantes. O MIT, por exemplo, distribui anualmente 350 mil dólares em prêmios para os alunos iniciarem empresas.

A Universidade de Aalto, na Finlândia, em 2009, tomando como modelo o MIT, deu início ao seu centro de empreendedorismo, colocando investidores em contato direto com professores e alunos e promovendo competições em busca de soluções ou aperfeiçoamento para suas demandas. Como resultado, empresas de tecnologia, como Nokia e Microsoft, doaram à Universidade um total de 18 milhões de euros no fim de 2009.

Como um filão na Finlândia é seu destaque no mercado de celulares, a Universidade de Aalto promove uma competição anual que dá prêmios de até 70 mil euros aos melhores aplicativos de alunos. O mesmo poderia ser desenvolvido pelas universidades brasileiras, atraindo talentos para os laboratórios de pesquisa e os preparando para o mercado de trabalho, além de atender às demandas de empresas interessadas, que financiariam os prêmios e futuras empresas. Um exemplo de aplicativos produzidos e utilizados em celulares que saíram de Aalto é o jogo para smartphones Angry Birds, dos fundadores da Rovio, que, desde 2009, foi baixado mais de 2 bilhões de vezes.

Para as universidades que partem do zero, reproduzir os modelos de Stanford e do MIT pode levar décadas. Contudo, exemplos demonstram que o investimento vale a pena, embora as universidades estejam atrasadas e os resultados possam demorar. Um exemplo é o Estado de Israel que, devido à sua necessidade de formar engenheiros para o Exército, começou nos anos 1980 a importar professores americanos.

Com a formação de engenheiros capacitados, multinacionais como a montadora General Motors e a fabricante de processadores Intel instalaram mais de 30 centros de pesquisa na nação israelense. Atualmente, o investimento 
do governo nas universidades visando ao estímulo para o empreendedorismo chega a até $90 \%$ dos custos iniciais de start-ups criadas por alunos das universidades.

Com milhares de empresas formadas, os fundos de venture capital acabaram atraídos para a nação. Em 2013, Israel teve o maior índice de investimento de capital de risco per capita do mundo - 170 dólares, ante 75 dólares nos Estados Unidos.

Exemplos como o da Universidade Technion, no norte de Israel, onde os professores têm total liberdade para investir ou se aliar a alunos na criação de start-ups, transformaram a cidade de Haifa numa das regiões com maior atividade de inovação do mundo. Países como Chile e China começaram, desde 2009, a adotar iniciativas semelhantes.

\subsubsection{Investimento privado}

Fato foi que a crise mundial de 2008 promulgou uma crise de financiamento das universidades de pesquisa de todo o mundo, incluindo investimento público e privado. É histórico que o número de invenções em universidades, hospitais e instituições de pesquisa é ditado pelo ritmo de investimento público, principalmente em países em desenvolvimento, como o Brasil. Nos demais países do BRICS e nas nações desenvolvidas, enquanto o número de invenções cresce, avançam também as patentes, os licenciamentos, as start-ups e os empregos. Segundo estudo da Association of University Technology Managers (AUTM), em 2010 foram registrados pelos seus afiliados valores da ordem de 2,4 bilhões de dólares com licenciamento de tecnologia. Embora a soma seja $3 \%$ superior aos dados de 2009, ela corresponde a um montante $30 \%$ mais baixo quando comparado com o ano de 2008, cujos valores somaram 3,4 bilhões de dólares em registros. As vantagens e interesses naturalmente devem destinar-se a ambos os lados, tanto empresas quanto universidades, sem deixar de lado o ator propulsor das ideias, o pesquisador. Benefícios existem para todos os envolvidos: a parceria dos laboratórios de pesquisas das universidades com as empresas é uma forma de partilhar custos em pesquisa e desenvolvimento em tempos de crise - o que tem sido uma necessidade principalmente para a indústria farmacêutica, carente de lançamentos de fármacos inovadores. Para as universidades e pesquisadores, há o retorno pelo licenciamento e royalties derivados da comercialização dos produtos gerados, além do fato de que a mão de obra especializada composta pelos alunos de mestrado e doutorado dos laboratórios de pesquisas 
pode atuar diretamente na produção e comercialização nas empresas. Para o Estado, considerando que as universidades sejam públicas e possa haver o viés de que o financiamento da pesquisa é público, de modo que não poderia ser utilizado para interesses privados, há o retorno por meio da geração de empregos, de impostos e a criação de novos setores econômicos. De acordo com o estudo da AUTM feito com universidades afiliadas, a pesquisa patrocinada por empresas manteve-se estável entre 2009 e 2010, com investimentos na casa dos 4 bilhões de dólares, enquanto os fundos federais subiram de 33 bilhões para 39 bilhões de dólares.

No Brasil, em 2003, foi criada a Agência de Inovação Inova Unicamp, da Universidade Estadual de Campinas, que tem o papel de associar o trabalho de proteção de propriedade intelectual com a prospecção de parcerias com empresas. A grande diferença entre o Brasil e os Estados Unidos diz respeito à capacidade e experiência em inovação, tanto do meio empresarial como acadêmico. No Brasil, ainda são poucas as empresas que investem em pesquisa e desenvolvimento. Já nos Estados Unidos o foco em inovação das empresas é muito maior que aqui, e uma boa parcela da comunidade acadêmica está engajada na inovação tecnológica. Entre 1980 e 2005, a Unicamp foi a vice-líder no país em patentes, com 405 depósitos no Instituto Nacional de Propriedade Industrial (INPI). Só perdeu para a Petrobras, com 804 depósitos. Entre 2000 e 2011, celebrou 53 contratos de licenciamento de tecnologia, sendo 10 só no ano passado, tendo gerado 2 milhões de reais em royalties desde 2005. Ajudou a fechar mais de 300 projetos colaborativos com empresas, num total de 65 milhões de reais. Também mantém uma rede de relacionamentos, denominada Unicamp Ventures, composta por empresários, na maioria ex-alunos, fundadores de mais de 220 empresas com vínculo com a universidade. Esses empreendedores constituem atores imprescindíveis do ecossistema de inovação da região, trazendo oportunidades, orientação e financiamento no apoio à criação de empresas start-ups. Exemplo para que as demais universidades públicas brasileiras, que chegam a 54 federais, com 321 campi", e 3 estaduais de destaque, todas no estado de São Paulo, tomem iniciativas em prol do desenvolvimento científico, tecnológico e regional do Brasil.

* Disponível em: http://painel.mec.gov.br/academico/mapaSupProf/acao/S). Acesso em: 12 maio 2014. 


\section{REFERÊNCIAS}

1. Vieira FV, Veríssimo MP. Crescimento econômico em economias emergentes selecionadas: Brasil, Rússia, Índia, China (BRIC) e África do Sul. Economia e Sociedade 2009; 18(3): 513-46.

2. Filho ETT, Puga FP. Investimento na economia brasileira: a caminho do crescimento sustentado. Rio de Janeiro: BNDES; 2007.

3. Fund IM. Slower growth in emerging markets, a gradual pickup in advanced economies. Washinton, DC: Update Weow; 2015.

4. Solow RM. A contribution to the theory of economic growth. The Quarterly Journal of Economics. 1956;70(1):65-94.

5. Development UNCTAD. Global value chains: investment and trade for development. $2013 ; 236$ p.

6. Bacha E. Os mitos de uma década: ensaios de economia brasileira. Rio de Janeiro: Paz e Terra. 1978.

7. Lederman D, Maloney WF. Does what you export matter? In search of empirical guidance for industrial policies. Washington, D.C.: International Bank for Reconstruction and Development/The World Bank; 2012.

8. Technologies A. The state of the internet. 2nd quarter, 2015 report; $2015.40 \mathrm{p}$.

9. Dutta S, Geiger T, Lanvin B. The global information technology report 2015. Geneva: World Economic Forum; 2016.

10. Neri M. Mapa da Inclusão Digital. Rio de Janeiro: Fundação Getúlio Vargas; 2012. 11. Knight PT. A internet no Brasil. Insuficiência estratégica restringe o progresso. Braudel Papers 2013;(48).

12. McKINSEY\&COMPANY. O ambiente empresarial no Brasil. Reflexões sobre a transformação nos últimos 25 anos e questões para a próxima década. 2013.

13. Brasil. Ministério da Ciência e Tecnologia. Pedidos e concessões de patentes de invenção junto ao Escritório Americano de Marcas e Patentes (USPTO, na sigla em inglês), de países selecionados, 1999-2014. [Internet]. [Cited 2016 Jul 12]. Available from: http://www.mct.gov.br/index.php/content/view/342765.html.

14. Brasil. Ministério da Ciência e Tecnologia. Brasil: Comparação dos dispêndios em P\&D (em valores de 2013) com o produto interno bruto (PIB), 2000-2013. [Internet]. [Cited 2016 Jul 13]. Available from: http://www.mct.gov.br/index.php/content/ view/9138.html.

15. Government of India. Department of Science \& Technology. [Internet]. [Cited 2016 Jul 12]. Available from: http://www.nstmis-dst.org/SnT-Indicators2011-12.aspx.

16. Brasil. Ministério da Ciência e Tecnologia. Dispêndios nacionais em pesquisa e desenvolvimento (P\&D), segundo setor de financiamento, países selecionados, 20122013. [Internet]. [Cited 2016 Jul 12]. Available from: http://www.mct.gov.br/index.php/ 
content/view/336712/Dispendios_nacionais_em_pesquisa_e_desenvolvimento_P_D_ segundo_setor_de_financiamento_sup_1_sup_em_relacao_ao_produto_interno_bruto_ PIB_paises_selecionados.html.

17. Brasil. Ministério da Ciência e Tecnologia. Pesquisadores em pesquisa e desenvolvimento ( $P \& D)$, em equivalência de tempo integral, em relação a cada mil pessoas ocupadas, de países selecionados, 2000-2013. [Internet]. [Cited 2016 Jul 12]. Available from: http://www.mct.gov.br/index.php/content/view/338279/Pesquisadores_ em_pesquisa_e_desenvolvimento_P_D_em_equivalencia_de_tempo_integral_em_ relacao_a_cada_mil_pessoas_ocupadas_de_paises_selecionados.html.

18. Country note. Education at a Glance 2015: OECD Indicators - Brazil. [Internet]. [Cited 2016 Jul 12]. Available from: http://www.keepeek.com/Digital-Asset-Management/ oecd/education/education-at-a-glance-2015/brazil_eag-2015-46-en\#page1.

19. Acemoglu D, Robinson J, Modenesi AM, Por que as nações fracassam: as origens do poder, da prosperidade e da pobreza: Rio de Janeiro: Elsevier; 2012.

20. Chen L. The world's biggest public companies 2015 Ranking. Forbes. 2015. [Internet]. [Cited 2016 Jul 12]. Available from: http://www.forbes.com/sites/laurashin/2016/07/11/ want-to-work-from-home-part-time-these-are-the-top-35-companies-hiring-so-far-in2016/\#697025414f2c 